\title{
Americans and Climate Change: Transnationalism and Reflection in Environmental Writing
}

Brian Glaser

\section{(2) OpenEdition}

\section{Journals}

Electronic version

URL: https://journals.openedition.org/ejas/10352

DOI: 10.4000/ejas.10352

ISSN: 1991-9336

Publisher

European Association for American Studies

\section{Electronic reference}

Brian Glaser, "Americans and Climate Change: Transnationalism and Reflection in Environmental Writing", European journal of American studies [Online], 9-2 | 2014, document 4, Online since 26 September 2014, connection on 08 July 2021. URL: http://journals.openedition.org/ejas/10352 ; DOI: https://doi.org/10.4000/ejas.10352

This text was automatically generated on 8 July 2021.

Creative Commons License 


\title{
Americans and Climate Change: Transnationalism and Reflection in Environmental Writing
}

\author{
Brian Glaser
}

\section{Confronting Global Climate Change as an American}

1 In his updated, expanded manifesto, Hot, Flat, and Crowded: Why We Need a Green Revolution-and How It Can Renew America, the New York Times columnist Thomas L. Friedman uses the term "American" as a measure for carbon emissions and resource use. The chapter "Our Carbon Copies (or, Too Many Americans)" begins with a description of the speedy growth of two urban centers-Doha, Qatar and Dalian, China -which gives way to a meditation on the environmental impact of this growth pattern, particularly with respect to global climate change. Woven into this reflection is his critical term: "Remember: the metric to watch is not the total number of people on the planet-it's the total number of 'Americans' on the planet. That is the key number and it has been steadily rising" (87). The scare quotes rather clearly beg the questionswhat is the difference between an American and an "American," and when does a person become an "American" in this problematic sense? For Friedman the difference between an American and an "American" is not so much a matter of the scale of consumption as it is a matter of answerability: "I certainly don't blame the citizens of Doha or Dalian for aspiring to an American lifestyle or for opting to build it on the same cheap-fossil-fuel foundation we did. We invented that system. We exported it" (87).

2 So what the phrase of the chapter's title-carbon copies-suggests in apparent playfulness as the relation between Americans and residents in industrializing cities ("Americans") turns out to be in a quite serious way the organizing logic behind the rhetoric of this section of the book. To be an American, with respect to the problem of carbon emissions and global climate change, is to own the problem and to have an 
original relation to it. One thing that follows from this for Friedman is that Americans have a unique responsibility to "use our resources and know-how to invent" solutions:

We Americans are in no position to lecture anyone. But we are in a position to know better. We are in a position to set a different example of growth.... In a world that is both flat and crowded, if we, as Americans, do not redefine what an American middle-class lifestyle is... we will need to colonize three more [sic!] planets. Because we are going to make planet earth so hot, and strip it so bare of resources, that nobody, including us, will be able to live like Americans one day. (87)

Americans have a moral responsibility to innovate, but they have a practical charge to do this as well, because "Americans" will copy what they do.

4 There is a muted but recognizable bit of American triumphalism in Friedman's way of framing this issue. It is of importance to pay critical attention to this dimension of global climate change rhetoric, particularly because it is a discursive field that is still taking initial shape in the United States. But in this essay I am interested to approach what seems to me the somewhat broader question of what happens in a culture when some of its creative members begin to look at themselves in the way that Friedman suggests, as units of environmental impact. In particular, I want to make some critical observations about the cultural dimensions of what Friedman calls the redefinition of "what an American middle-class lifestyle is" in response to the urgencies of global climate change, especially as this redefinition is being carried out in the domain of print culture. For a number of books published within the last few years-I will discuss Colin Beavan's No Impact Man, Doug Fine's Farewell, My Subaru, and Kurt Hoelting's The Circumference of Home-narrate the efforts of their authors to live over a sustained period of time in a way that is designed to mitigate their impact on climate change. These books fit into the broader category of environmental life writing, which is itself a field in relative critical neglect, but my focus here on works by Americans who are explicitly concerned with global climate change can give us a sense both of how American culture is coming to terms with this issue in the years since the release of $A n$ Inconvenient Truth and of how the genre of life writing has evolved into a significant element of print culture's engagement with environmental thought.

5 Each of the writers of these texts is set to his project in part because of his sense that he participates in an American culture that generates a disproportionate amount of carbon gas and that has yet to establish the terms of a promising political conversation about how to address this. Their turn to the work of action on a personal rather than collective scale can be read in a number of ways-as a sign of misgivings about the possibility of Friedman's green revolution, or as a commitment to the ideal of writerly leadership that has animated the American environmental movement since Silent Spring, or as a creative response to the intensified sense of urgency surrounding climate change in popular culture since the release of Gore's film. But by designing experiments in living that lead them to be responsible for smaller carbon emissions, these writers also deliberately marginalize themselves from the American mainstream and its default position with respect to greenhouse gasses-flagrantly culpable and unsure what to do.

6 Reading these three works of climate change life writing in the context of the transnational turn in American literary studies, I think they can be seen to provide us with a valuable form of knowledge for living in the era of sociogenic climate change. ${ }^{i}$ Beavan, Hoelting and Fine look at themselves as Americans from a global perspective, and this provokes them to undertake creative projects that represent various ways that 
one can be an engaged American in the era of sociogenic climate change. In each of these three texts, the writers discover that their sense of purpose changes as they encounter different forms of rationality with which they share the experience of living purposefully in the world. Acting as an American world citizen involves a particular form of reflection-adapting to the perspectives one is brought to by encounters with others. ii

7 The significance of this reflection needs to be demonstrated. By inviting here a larger conversation about climate change life writing as a genre, I hope to contribute in some way to that project already. But I will give a polemical edge to this essay with a few remarks intended to do more in this regard, setting my claim for these works alongside the ideal of ecocosmopolitanism that has been articulated elegantly and forcefully by Ursula K. Heise. She writes that "environmental literature and ecocriticism need to engage more fully with the insights of recent theories of transnationalism and cosmopolitanism" (383). Specifically, she has argued in ALH and in Sense of Place and Sense of Planet that local forms of identity and knowledge should be seen to be in a kind of determining subordination to global forces and contexts. As a caution and an invitation, Heise's argument seems to me important.

8 But there is a dimension of Heise's rhetoric of ecocosmopolitanism that can be usefully interrogated by attention to the particular form of reflection that I see to be articulated in climate change life writing. In her critique of Barbara Kingsolver's Animal Dreams and Ruth Ozeki's All Over Creation, Heise points out a deficiency:

By offering multicultural and sometimes transnational family romances as narrative resolutions of ecological conflicts, or by using biological and cultural diversity as direct metaphors for each other, such texts seek to appropriate the oppositionality of the transnational subject even as they remain resolutely local in their opposition to globalization. (387)

9 Her readings demonstrate how these substitutions do real affective work in the structuring of her two texts. But in her move from these particular books to a discussion of the holes in "environmental literature and ecocriticism" as fields, it seems to me that Heise puts an unwarranted degree of trust in the transparency-I would even say the coherence-of the term "the oppositionality of the transnational subject." ${ }^{\text {iii }}$

10 The implicit normativity of the definite article gives one pause. Is this oppositionality a necessary condition for being a transnational subject? And whatever the answer to that question might be, can this oppositionality be in any sense uniform among various transnational subjects? Heise seems to accept a binary hierarchy which contrasts the cosmopolitan or transnational with its other-be that the local or the nationally identified-and assigns valuable oppositionality to the cosmopolitan. The more full engagement with cosmopolitanism that she recommends seems to involve acceding to a concept and an expectation of oppositionality that are perhaps unfortunately normative in a number of respects.

1I want to repeat that I take Heise's cosmopolitan challenge to Americanist ecocriticism to be valuable. Works like Beavan's, Hoelting's and Fine's, which do not develop themes of multicultural interaction with anywhere near the complexity that they afford composting and solar panel installation, should be provincialized. But the provincializing of these books should not prevent us from seeing the quite novel and also valuable ways in which they contribute to transnational American literature. 
These authors are taking up identity as Americans from a global perspective, and they attempt to model a kind of responsible world citizenship from inside of this frame. In their reflective quality, they carry environmental writing beyond the naivety of much nature writing.

12A narrative that binds transnational consciousness and oppositionality will not dwell on the political value of these books for addressing the problems of global climate change. But I think their creativity makes the possibility of meaningful and demanding change in American patterns of fossil-fuel use enlivening and concretely foreseeable. There are of course questions about how these life experiments could be scaled in a significant way, and some of these authors address those questions with only equivocal answers. Still their works creatively realize visions of American identity in the era of sociogenic climate change from a global point of view. And this realization offers knowledge that is valuable for many forms of progressive politics, including any oppositional politics-the knowledge that subjects' purposes can evolve as they encounter and reflect on diverse forms of rationality.

13 In the most direct sense, these works offer what Ottmar Ette calls Lebenswissenknowledge for living-in the era of sociogenic climate change by showing what can be done practically by individuals to address the problem of global climate change. But Ette's discussion of the concept of literature as knowledge for living in his 2004 ÜberLebenswissen can allow us to see another way in which these books offer exemplary figures who facilitate cultural change to combat global warming, a way which is also important and perhaps not as obvious as the practical dimension of the books. "Lebenswissen wird jedoch nicht nur durch konkrete Erfahrungen in unmittelbaren Lebenskontexten sondern auch durch die Produktion und Rezeption symbolischer Güter, durch die unterschiedlichsten Aneigungsformen von Kunst und Literatur gewonnen" (12). ${ }^{\text {iv }}$ If we look at the texts in the genre of climate change life writing as participating in the production and reception of symbolic goods that generate knowledge for living, we can see them as the instigators of an economy in which narrated experiences are useful not only for their immediate practical suggestions but also for the forms of knowledge that can be brought about by the symbol-employing processes of identification and reflection. Gaining knowledge for living from a written narrative involves the experience of seeing another for a time as a symbol for oneself, imaginatively living as him or her in order to reflect on how the world looks from his or her subject position, how one would respond to circumstances differently than the other does, and how one can benefit from his or her perspective and values.

14It is in this spirit that I want in the section that follows to offer some thoughts on the characteristic reflectiveness of American climate change life writing. But before I do that, I want to stay with Ette's discussion of Lebenswissen just a bit longer, because it seems to me that his contextualization of literature as symbolic exchange describes well how knowledge for living of a more reflective kind is created by these texts. It is also at this point that it seems to me Ette's arguments begin to become rather clearly distinctive among critics who have approached the question of literature's forms of knowledge, a tradition that ranges across Kenneth Burke's concept of symbolic action and Martha Nussbaum's plea for love's knowledge. Addressing the problematic breadth of the concept of Leben or life in its relation to his arguments, Ette says this

Einen endgültigen Begriff von dem, was Leben ist, wird glücklicherweise auch das

21. Jahrhundert nicht entwickeln können. Die Einsicht, 'daß Rationalität plural ist', 
bietet eine gute Grundlage, um unterschiedliche Logiken, verschiedene Kulturen,

Künste und Wissenschaften zu Wort und zu Gehör kommen zu lassen. (20)v

The quote in this passage comes from Lorraine Daston's Wunder, Beweise und Tatsachen. But it is an important one for apprehending Ette's own message. The search for knowledge for living begins with the acknowledgement that rationality is plural. Just as various discursive fields-logical, artistic, scholarly and cultural-intersect within the word "life," so the forms of knowledge that literature offers about life by symbolic means will intersect, overlap and perhaps conflict.

16 To read American climate change life writing with this in mind is to be aware that the authors of these books are, for all of their disciplined focus on the exigencies of their experiments, often shaped by ways of living, ways of being and thinking, that contest with their own. An important dimension of the knowledge for living that these books offer is the experience of identification with someone whose actions to fight climate change develop and evolve in response to the influence of others with whom his experiment becomes somehow shared. In a national culture where meaningful collective action to address the problem of global warming seems to be blocked by large, even enormous, economic and political obstacles, an important part of the work these texts do is to show the climate change counterculture ways of being both oppositional and reflective. Helping concerned citizens to cope with being situated in a material context where everyday life is in some ways at odds with their political and environmental visions can involve not only inspiring those citizens to reach in more extreme ways towards carbon neutrality but also representing the process of negotiating among the demands of many forms of rationality-many worldviews and systems of values-while one lives the dictates of one's own social and environmental conscience. Knowledge for living, at least for Americans in the era of sociogenic climate change, can-and, these authors seem to imply, should-involve reflecting on the diverse forms of rationality one encounters while pursuing a minimal carbon footprint in such a way that that diversity might lead one's own sense of purpose to evolve, to be open to change. What I mean to say by calling the forms of life with which the authors share their projects forms of rationality is that while they sometimes initially present themselves as not entirely open to the message of global climate change, they are not understood as irrational opponents by the authors of these texts. They are life forms with their own purposes and ideals which have integrity in their coherence and sense of identity.

17 Each of the books I discuss in the following section narrates a version of this process. They begin with an awakening of a kind, in which the scale of the problem of global climate change makes it seem both urgent and threateningly large, and this leads to the crafting of a project for modeling ideal behavior for an individual. In the course of carrying out this project, the authors encounter other forms of rationality, and this leads to a reflection on their project-a moment of seeing it through the eyes of another-which instigates a changed sense of purpose. In contrast with the picture of these experiments that emerges from the blog posts of the various authors, which tend to focus on the details of practical steps towards carbon neutrality, the booklength narratives situate knowledge for living in a less carbon-intensive way as a project which is modified by relation and, consequently, reflection.

18 One might think of the genre of climate change life writing as responding to the cultural need for reflection in environmental writing demonstrated by the purported 
naivety of popular American nature writing. Timothy Morton in Ecology without Nature ("The immediacy that nature writing values is itself as reified as a Coke can"; 125) and Dana Phillips in The Truth of Ecology ("this writing leans more toward the private, inner world of the self, a place where tremulous sentiment rules, than toward the public, outer world of nature and culture"; 210) offer critiques of the genre that suggest that it has failed to live up to the praise for it as a mode of thought which is articulated in Lawrence Buell's The Environmental Imagination. This is perhaps overly polemical-there remains a great deal of diversity in this field of writing. But I think it can be argued that there is a valuing of the experiential and the concrete in the tradition of nature writing that is modified in a significant way in climate change life writing. The emphasis on the immediate and the particular continues in the works of climate change life writing that I discuss in this essay. Animals appear in each of the three texts, and they are particularly important to Fine and Hoelting. But the way that these writers relate to their environment is mediated by their knowledge of the problem of sociogenic climate change. Nature does not hold out for them the promise of a transformative moment of awareness, as it does in much of the nature writing tradition created before the acknowledgement of the era of sociogenic climate change. Nature is seen by these writers as, in the way that Bill McKibben has been arguing for decades, irrevocably changed by climate change. And it is this awareness of mediation or transformation that sets the writers of climate change life writing to their task. There is a sense for each of them that immediacy in relation to nature would be an escape.

\section{Life Writing, Knowledge for Living}

19 Like a number of other books in the genre, Colin Beavan's No Impact Man has in its opening section an acknowledgement-in this case indirect-that Al Gore's film was an inspiration for his project:

A year or so later [after 2004], news about global warming started coming out. I mean, it's been out for twenty years, but somehow it hadn't entered my liberal consciousness. We can't maintain this way of life, the scientists said, the world can't sustain it. The ice caps will melt, the sea levels will rise, there will be droughts-or, in short, the planet will be done for and millions of people will suffer. (6)

It is the social urgency that the cause has in the moment as much as the environmental threats of which he has become aware that impels Beavan. But this U.S. cultural phenomenon leads him immediately to a reflection on the implications that a recognition of global climate change might have for his identity as an American citizen:

The countries of the world had negotiated the Kyoto Protocol to the United Nations Framework on Climate Change, assigning mandatory targets for the reduction of greenhouse gases to signatory nations. But the United States, a signatory to the protocol, as well as the world's largest producer of greenhouse gases, refused to ratify it.

What had I done in light of our country's deaf ear to environmental concerns? (6)

Beavan begins by seeing himself as an American from a global perspective, and this leads him to a feeling of being representative in an uncomfortable way-powerless but culpable.

$22 \mathrm{He}$ questions whether indeed he is as powerless as he has told himself he is, and finds that individual action might be more meaningful than it had seemed. The project that he develops after this reassessment is extreme but simple: 
As an experiment, I'd simply dedicate a year of my life to researching, developing and adopting a way of life for me and my small family-one wife, one toddler, one dog-to live in the heart of New York City while causing as little harm to the environment as possible... . My idea was to go as far as possible and try to maintain as close to no net environmental impact as I could. (14)

Sections of his project included minimizing his waste, eliminating carbon-based transportation, and eating only locally grown foods to reduce the food-miles in his diet. But one dimension of the experiment that he neglects to mention here is writing about and publicizing the project, which he did in a number of ways-by keeping a blog, appearing in dozens of prominent media stories, and co-producing a film about his efforts. To an extent unmatched by other authors in the genre, he created an aura of celebrity around himself and his family.

24But the family participated in the experiment in ways that could not be orchestrated. Repeatedly in the early pages of the book he narrates his wife Michelle's skepticism and resistance, which gradually shift to a spirit of enthusiastic participation. His family of origin is a different story-after causing conflict and anger on declaring that he won't be bringing his family to visit his parents for Thanksgiving or to attend a baby shower for his sister, Beavan decides to break his self-imposed rules and make a train trip to New England to visit his parents and sister for Christmas. Negotiating between his identity as No Impact Man and his role as a son becomes a source of torment, though, on December 25, when the sight of wrapping paper being torn open in profusion drives him to distraction. His sister laughs at him. His wife calls him a freak. And he confesses to the reader, "I don't like what the project is doing to me lately. I feel I have to control everything" (110).

25This sense of being estranged from his family and even from himself leads him to a moment of critical self-reflection: "It's like pulling a ball of string that starts to unwind. Instead of just thinking, How do I live without harming the environment? I find myself asking: How shall I live?" (110). The question has consequences. Immediately following the Christmas episode he writes of a conversation with Michelle about having another baby-she has "wanted a second child forever," and he is "worried about our ability to afford and care for another baby" (110-111). With no coaxing other than the invitation to "play Russian roulette," Beavan agrees to the possibility of another child, which agreement he calls "in some unspoken way... a quid pro quo for her participation in the project" (111). Beavan does not directly acknowledge the awkward fit that this openness makes with his project-the environmental impact of fathering a child is probably impossible to measure, but of course by no means negligible-but this reflection is tacit in the words with which he closes this passage: "I'm faced with myself again. You see what I mean? How shall I live?" (111). In the context of his relationship with Michelle, and in its rhetorical turn to the presence of another-you see what I mean?-this passage suggests that Beavan has discovered the extent to which he depends on a sense of belonging to his family in order for his life-project to seem sustainable.

26 Shortly after this section, Beavan reflects on the "truth" about his "motivation" for the No Impact project, and he suggests that a sense of perplexity and confusion that can be traced to the death of his brother at eight months old might have more to do with it than "polar bears or corrupt politicians" (113). His explorations of this make it seem plausible, though this section of the book might strike some readers as underdeveloped. But apart from whether this interpretation of his project is persuasive 
there is the significant fact that he is brought to this reflection by a sense of just how much he needs to feel the companionship of family in order to make his project sustainable for himself. The conflict-induced contradiction of changing his approach towards birth control in the course of his no impact year is a louder signal, to me, than his own introspection of the extent to which he finds that over time he wants to incorporate the values of others into his own assessment of what kind of impact on the planet is desirable for him to pursue.

27 Kurt Hoelting's The Circumference of Home is subtitled "One Man's Yearlong Quest for a Radically Local Life." Like Beavan's, Hoelting's book departs from the premise that the experiment will be the project and test of one man. And like Beavan he acknowledges, while discussing his motivations for the project, the influence of Al Gore (in this case, by citing in a footnote "Al Gore's organization We Can Solve the Climate Crisis") (253). This organization is where he found the online carbon footprint calculator that he used to come to this radicalizing perspective on himself:

To my amazement, I discovered that my carbon footprint was more than twice the national average, in spite of the fact that I drive a hybrid vehicle and work hard to limit my personal use of energy. Since the average North American carbon footprint is ten times the world average, this was an alarming discovery. For someone who prides himself on living low on the energy food chain, this was not something I could take sitting down. (xiii)

Hoelting sees himself as a North American from a global perspective, and this commits him to a "radically local life" for a time, in large part because the source of his oversized carbon footprint is the amount of airplane travel that he undertakes in a year (xiv). He chooses an alternative to "feeling powerless," and determines to "spend an entire year within walking distance of home," which is a significant turn away from flight in both a literal and metaphoric sense (xiv). He limits himself to the region within a sixty-two mile radius of his home (xv). The motif through which he imagines his experiment is "homecoming," and its spirit is to eschew the act of escape in favor of the labor and pleasure of return. Instead of knowing the globe as a jet transports him through it, he designs a year in which his three modes of knowing his environment will be by walking, biking and paddling a kayak.

29 Especially in the first of these three projects, Hoelting discovers that he feels intensely alienated from the life of his locality. Living in the somewhat insular culture of Whidbey Island in Washington, he stresses towards the beginning of the book that he finds the islanders' phrase for visiting the mainland particularly appropriate-"going to America" (6). He dreads it: "'Going to America' trades a semblance of rural cohesiveness for an empire of sprawl-shopping malls, commercial strips, instant subdivisions springing up like mushrooms, and ever-more-congested highways" (6). The initial stages of his trip only confirm for him that he is lucky to be estranged from America; he reflects on the influence that the car has had on the architecture, pace and social fabric of American life-"Americans own more cars per capita every year," they are beset by the "American ideal of hyperindividualism," and driving is a "uniquely American pastime" (9).

30 This alienation is only deepened as he continues his walking tour of his local environs, and stops at Don's 24-Hour Café: "I attempt some friendly banter with the waitress, but she takes my order on the fly and is gone. She asks no questions and betrays no curiosity. Nor does anyone else. The conviviality of the place doesn't extend to me" (25). Hoelting feels that this is because of his "backpack and REI clothing," but 
he also speculates that "red state/blue state distinctions" are operative in his experience of ostracism (25). America itself is a divisive body, and its divisions distort perhaps even for Hoelting himself the values and hopes that guide his project.

31 Another encounter later in his walking tour gives texture to this sense of alienation. As Hoelting enters the town of Stanwood looking for lodging, he meets a woman at a bus stop. They strike up a conversation in which the woman tells him about her life since being released from prison, a good bit of which has been devoted to raising the child her daughter had at the age of fourteen. "Her story puts my own small dilemmas in sharp relief," he says (47-8). But her story also puts him in mind of Vaclav Havel, the playwright and political prisoner who became the president of Czechoslovakia and the Czech Republic-he thinks of Havel's definition of hope as "the certainty that something makes sense, regardless of how it turns out" (49). It is an association that he keeps to himself, and perhaps appropriately-for though it gives the readers a sense of how he has been affected by this encounter, it is also a flight of a kind, from "America" to a distant place and culture.

32 His sense of alienation from America is changed decisively by another kind of flight, however. Walking through the skagit delta, located in northwestern Washington, with his wife Sally, Hoelting encounters "flock after flock" of snow geese, which "pile like snowdrifts against the curving edge of the slough, then settle down for a long lunch" (62). As he and Sally themselves settle in for lunch, Hoelting watches the geese and marvels that the flock "seems to function like a single organism" (62). He considers this, and then reflects:

Yet a small number of informed individuals can have a decisive impact on the flock as a whole, even if these individuals are not recognized as leaders and do not recognize each other. It is known, for example, that 5 percent of a honeybee swarm can guide the group to a new hive. And for migrating groups of animals, the larger the flock, the smaller the number of informed individuals needed to effect a change in direction. The result is that unanticipated shifts in the direction of travel that benefit the whole flock can happen with breathtaking quickness. (62)

33 This fact is immediately present to Hoelting as a metaphor that helps him to understand the relation of his own project to the masses in a different way: "Maybe we don't have to all get it before the flock gets it" (63).

34 The chapter ends with Hoelting and his wife finding their way to the home of friends for dinner, and he reports that they "have a deeper sense of what it means to be inhabitants of this place" (65). But his sense of connection to America is modified, too. Instead of being a name for the culture of the automobile and hyperindividualism that he mentioned earlier, America is reframed in the terms that Gary Snyder offers in The Practice of the Wild, and becomes the name for a place that is inhabited in a caring and thoughtful way. Hoelting quotes Snyder:

There are tens of millions of people in North America who were physically born here but who are not actually living here intellectually, imaginatively, or morally. Native Americans to be sure have a prior claim to the term native. But as they love this land they will welcome the conversion of the millions of immigrant psyches into fellow 'Native Americans.' (70-71)

This is quoted in full in the book because it describes the shift that Hoelting himself has undergone in the course of his walk, as a sustained walking exploration of a place exposes him to an alternative paradigm of flight, one that allows him to feel a greater sense of belonging to his environs and to America. One important development in the 
course of Hoelting's walking tour is that the binary opposition between home and America that had organized his spatial identity is destabilized. Yet more significantly, through his encounter with the snow geese flight itself has become transformed into a metaphor that invigorates his efforts to live sustainably rather than being only a practice that he chooses to excise from his life.

36 This changed relationship to America as a native land has an important consequence for his project. In the course of his year, he chooses to travel outside of his self-prescribed "circle" in order to participate in a Native canoe rendezvous:

The fact that this event is taking place outside my circle only increases its appeal as the object of my first kayaking pilgrimage. It is in the spirit of the occasion that I should be willing to leave my home waters, joining canoes that have in many cases journeyed much farther from home than I have, in an effort to stitch the ancient culture of this coast back together. (185)

The story of his trip to participate in this event ends with a return to the U.S. that confronts Hoelting with the geopolitical complexities which can be involved in this kind of effort to connect culture to place. And so he has been drawn clearly and consequentially away from his original purpose by reflection and the experience of becoming a Native American in Snyder's sense, "living here intellectually."

Doug Fine's Farewell, My Subaru begins with a similar attempt to embrace a sense of home, as the author has chosen to settle in New Mexico after decades of itinerant journalistic work. There are other similarities with Hoelting-the book is presented as an "adventure in local living," and, in an unmistakable marker of the genre, the book acknowledges the influence of $\mathrm{Al} \mathrm{Gore.} \mathrm{In} \mathrm{Fine's} \mathrm{book,} \mathrm{characteristically,} \mathrm{this} \mathrm{debt} \mathrm{is}$ mentioned in a spirit of humor-after watching his Subaru roll away from him at his recently purchased ranch, he uses the occasion to imagine a new beginning: "I figured I would forge success from astonishing, seemingly irrevocable defeat, you know, like Al Gore" (4).

39 Fine's project, presented as a response to the reality of both global climate change and peak oil, is "to see if a regular guy who enjoyed his comforts could maintain them with a reduced-oil footprint" (5). This is how he describes it in a direct address to the reader at the start of the work. In a narrated conversation with Lacy, "a lifelong New Mexican," Fine puts the project somewhat differently, though representing himself with the same evidently cherished term: "I'm trying to show that a regular American can still live like a regular American, only on far fewer fossil fuels"' (12).

40 The complexities that Fine subsumes into his identity as "regular American" become clear early in the book. In a section that begins with a realization that he is "hopelessly dependent" on Super Wal-Mart in his new locale, Fine narrates his various trips to the box store and works towards a "vow to avoid box-store shopping" that is an occasion to imagine his relationship to the commodity economy as one of weaning towards self-reliance:

I was going to dive into this project with everything I had.... I would do it one project at a time. Maybe after a year, I'd see some real reduction in the oil in my life. But it wouldn't be a cakewalk. At the moment, even with solar panels, I would survive as long as crunchy co-ops imported tomatoes and box stores provided preroasted protein. (27) 
41 The irony with which he views himself stresses a sense of how exemplary this project might be. To be a "regular American" with a reduced carbon footprint will mean replacing commodities with "comforts" that he has produced himself.

42 This attempt to withdraw from market exchange Fine treats with a sense of playfulness, which allows him to register its contradictions-as when he presents his project as entailing "in concrete terms... bank-account draining investments in solar power"-as well as the substantial challenges it presents to his habits of selfconfirmation-as when he longs to celebrate his sense of being "responsible" for his own "future protein," which will be produced by two goats, with a "mass-produced domestic beer" $(5,44)$. But despite this light touch, Fine clearly begins the project with the ideal of becoming "independent," a term he uses repeatedly and which serves as an important shadow to his identity as a comfort-loving regular American $(15,29)$. Implicit in his jocular discussions of investing in solar power or celebrating his start as a farmer with a mass-produced beer is the expectation that he will negotiate the tension between being independent and being a regular American by purchasing his way to self-reliance.

43 Woven in a not very clearly conceptualized way into his pursuit of a smaller carbon footprint is the desire to buy his way out of the commodity economy. This turns out not to be possible for him, though, as he discovers that the sorts of goods he needs to purchase in his pursuit of independence often involve him in relationships with the vendors that continue or deepen beyond the exchange of cash for commodity. He buys two goats from Janice, a woman living in Arizona, who gives him advice on traveling in a flooded area, feeding the goats, and injecting them with medicine, and gives him her phone number along with the invitation to call her with "any problems" (40). Though tending the goats turns out to be fraught with a fair number of problems, Fine does not call. In his interactions with Kevin Forrest, an Albuquerque mechanic who converts his automobile to run on vegetable oil, he finds himself yet more implicated in a relationship of commodity exchange that does not end with the transfer of money and goods:

After seventy-two hours and a dozen trips to NAPA auto supply, Kevin declared my truck 'converted.' As he was waving a monkey wrench the size of a golf club over the vehicle, his proclamation actually had a somewhat spiritual ring to it, though I've seen formal religious conversions that took less time. In fact, since I'd just gotten splattered head to toe in vegetable oil from assisting in a minor hosetightening mishap that Kevin called my 'anointing,' I felt as though I had just been through what any theological scholar would call a religious conversion [.] (82)

Fine and Forrest collaborate, discover and work around their very different political orientations and attitudes towards George Bush, and share this playfully religious language to describe their interactions.

45 The installation of the much-anticipated solar panels at the ranch eventuates as another occasion where Fine is involved in a relationship through commodity exchange. In this case, his solar panel installer, Jimmy 0 , requires his help because high winds kick up on the day when he arrives to mount them thirty feet up on a windmill. Fine presents his response to this circumstance in his habitually antic mood:

Jimmy had blessed me with his expensive presence after literally six months of lobbying. It had been like planning a bar mitzvah, right down to the catering. We couldn't reschedule just because the spring winds had chosen to move in this exact day. It could be months, even years before he'd come back. So instead of pleading 
for my life, I had to force myself to assist in the project. This meant saying things

like, 'Would you pass the three-eighth adjustable wrench, pardner?' (110)

Fine's pursuit of independence is thoroughly undermined here-not only does he need the solar panels for his project, but he becomes an unpaid assistant to the person he has paid to help make him self-reliant. Purchasing has taken him outside of the relationship of commodity exchange, but not in a way that can be characterized as independent.

47 Fine is not one to brood on such things. There are at least two signals that his strategy for becoming an independent regular American has changed in the course of the project, however. One that is perhaps overdetermined by narrative convention is his discovery of a satisfying romantic relationship by the end of the book: "My neighbor Sandy was right when she told me that mine was a two-person task, but not because it made the chores easier. Rather because it made life infinitely more joyful" (189). A perhaps more telling indicator of the shift in his sense of purpose comes when he rewards an assessor with a carton of eggs for approving his questionable application for status as a working ranch (149). In a sense, both the approval and the gift are signs of how he has become appreciably self-reliant. But if they represent his movement away from the cash-for-commodity paradigm of exchange he meant to flee, they do this not so much as a passage into independence as into a mindset in which the exchange of commodities implies collaboration and relationship.

\section{Conclusion}

48 The era of sociogenic climate change demands more from print culture than a nature writing which longs for immediacy. But Heise's call for ecocosmopolitanism shouldn't keep us from seeing how writers who can be provincialized are living with the diverse consequences of thinking in broader terms than nationality provides. These include not only oppositionality but also relation and reflection. Beavan, Hoelting and Fine offer knowledge for living as an American who eschews the immediacy of nature writing and who takes seriously the global environment.

49 Heise has done both American Studies and environmental criticism a great favor by introducing the concept of ecocosmopolitanism. Thinking in global terms is essential for articulating a politics of the era of sociogenic climate change. But her strategy of staging the ecocosmpolitan citizen as necessarily oppositional and of provincializing some forms of solution-oriented thinking is, I venture to suggest, a kind of essentializing binary thinking that can limit the resources with which we identify how American culture is coping with the knowledge and challenge of global climate change. Rather than construct a binary with the role of the ecocosmopolitan at one pole, I suggest that we might use the term as an ideal that creates a spectrum along which we can see various efforts at solving environmental problems to fall. The global awareness that each of the authors I discussed manifests is perhaps imperfectly cosmopolitan, but it represents a global consciousness nevertheless. I believe that it is a decided improvement over the immediacy of awareness that much of the nature writing tradition offers, and one that is fair to call innovative in the tradition of Walden. 


\section{BIBLIOGRAPHY}

Beavan, Colin. No Impact Man. New York: Farrar, Straus and Giroux, 2009. Print.

Buell, Lawrence. The Environmental Imagination. Cambridge: Belknap, 1996. Print.

Carson, Rachel. Silent Spring. New York: Houghton Mifflin, 2002. Print.

Ette, Ottmar. ÜberLebenswissen. Berlin: Kulturverlag Kadmos, 2004. Print.

Fine, Doug. Farewell, My Subaru. New York: Villard, 2008. Print.

Friedman, Thomas L. Hot, Flat, and Crowded. New York: Picador, 2008. Print.

Heise, Ursula K. "Ecocriticism and the Transnational Turn in American Studies." American Literary History 20: 381-404. Print.

---. Sense of Place and Sense of Planet. Oxford: Oxford UP, 2008. Print.

Hoelting, Kurt. The Circumference of Home. Philadelphia: Da Capo Press, 2010. Print.

Malm, Andreas, and Alf Hornborg. "The Geology of Mankind? A Critique of the Anthropocene Narrative." The Anthropocene Review 1.1 (2014): 62-69. Print.

Morton, Timothy. Ecology without Nature. Cambridge: Harvard UP, 2007. Print.

Phillips, Dana. The Truth of Ecology. Oxford: Oxford UP, 2003. Print.

Ross, Andrew. "The Great White Dude." Constructing Masculinity. Ed. Maurice Berger, Brian Wallis, and Simon Watson. New York: Routledge, 1995. 167-175. Print.

\section{NOTES}

i. I agree with the argument made by Andreas Malm and Alf Hornborg that climate change is better described as "sociogenic" than "anthropogenic" (66) because "intra-species inequalities are part and parcel of the current ecological crisis and cannot be ignored in attempts to understand it" (62).

ii. Particularly since the three authors I study are white males, it's important for me to stress that the salient characteristic I treat in each text is the way that these men are open to change because of an encounter with another living being. They are in a way the opposite of the kind of "ecological superman" that Andrew Ross discusses in "The Great White Dude" (167). They are not lone heroes perpetuating the myth or mentality of the rugged individualism of the white man in American culture-they are partners in dialogue with other human beings and other species as they seek to live in sustainable and non-damaging ways.

iii. While it is not made entirely clear what Heise means by "oppositionality," I take it to mean a resistance to hegemonic forces in American culture, refusing to assent to participation in what is normatively constructed as American.

iv. Knowledge for living is not only gained through concrete experiences and immediate contexts of life, but also through the production and reception of symbolic commodities and through the most diverse forms of adoption of art and literature.

v. The twenty-first century too will, fortunately, not be able to develop a definitive concept of what life is. The insight "that rationality is plural" offers a good foundation for allowing diverse logics, and different cultures, arts and scholarly disciplines to speak and be heard. 


\section{ABSTRACTS}

This article reads three American works of climate change life writing in order to examine how print culture in America is responding to growing awareness of the threat of global climate change. Engaging with Ursula Heise's work on American environmental writing, I argue against a binary conception of cosmopolitan and provincial responses to this threat, seeking to show how ambitious individual reactions to climate change are complicated and enhanced by ways of relating and collaborating with other humans and other species.

\section{INDEX}

Keywords: climate change life writing, ecocosmopolitanism, knowledge for living, sociogenic climate change

\section{AUTHOR}

BRIAN GLASER

Chapman University 